\title{
PAISAJE Y TERRITORIO. \\ Revisitando conceptos a partir de las transformaciones del paisaje pampeano argentino.
}

\author{
Martínez de San Vicente, Isabel; Galimberti, Cecilia; Jacob, Nadia \\ Consejo Nacional de Investigaciones Científicas y Técnicas (CONICET) - Centro Universitario Rosario de \\ Investigaciones Urbanas y Regionales (CURDIUR). FAPyD, Universidad Nacional de Rosario (UNR). \\ Argentina. \\ Directora: Dra. Arq. Isabel Martínez de San Vicente \\ isabelmartinezdesanvicente@gmail.com
}

\section{RESUMEN}

El presente trabajo se propone revisar, desde la perspectiva de los estudios territoriales, los conceptos de paisaje y territorio. Estos términos resultan componentes complejos, polisémicos, transdisciplinares y son abordados desde diversas miradas a través de la historia.Desde esta perspectiva, se propone interpelar la noción de paisaje rural, para lo cual se toma como caso de estudioal territorio pampeano del sur de la provincia de Santa Fe, Argentina. Se considera que dicho paisaje, a pesar de las diversas transformaciones y cambios a lo que es sometido desde su conformación hasta la actualidad, presenta permanencias que nos conducen a reflexionar sobre la identidad del territorio y su utilidad como herramienta para enriquecer los instrumentos de ordenamiento territorial contemporáneos. Es así que se pretende contribuir al conocimiento teórico y metodológico de los estudios territoriales a fin de desarrollar nuevas herramientas cognoscitivas y de intervención territorial.

Palabras clave: paisaje rural - territorio - ruralidad - ordenamiento territorial

\begin{abstract}
The present work intends to review, from the perspective of territorial studies, the concepts of landscape and territory. These terms are complex, polysemic, transdisciplinary components and are approached from various perspectives throughout history. From this perspective, it is proposed to address the notion of rural landscape, for which the case is taken as the case of Pampas territory in the south of the province of Santa $\mathrm{Fe}$, Argentina. This landscape, despite the various transformations and changes to what is submitted from its formation to the present,registerpermanencies that lead us to reflect on the identity of the territory and its usefulness as a tool to enrich the instruments of contemporary territorial ordering. It is thus intended to contribute to the theoretical and methodological knowledge of territorial studies, to develop new cognitive and territorial interventiontools.
\end{abstract}

Key words: rural landscape - territory - rurality - territorial planning 


\section{INTRODUCCIÓN}

La planificación territorial se ha renovado de una manera no lineal en distintos momentos de su desarrollo, a partir de una serie de continuidades y de rupturas que han dado lugar a nuevos planteamientos y nuevas concepciones, generando a su veznuevas miradas en torno a nociones anteriores. La planificación contemporánea es un espacio de reflexión, en el cual convergen diversas ópticas disciplinares, y por lo tantodiferentes líneas de investigación y reflexiones epistemológicas. Desde nuestra perspectiva, interpelamos al paisaje como objeto de la observación y de la descripción, como realidad percibida, como manifestación de las interacciones entre los elementos físicos y entre éstos y los grupos; y al territorio como hecho social y político, lugar de la intervención técnica. Son estas condiciones de uso y de forma que no son meramente utilitarias, sino que admiten valoraciones estéticas a la vez que proveen interpretaciones estructurales, las que introducen su condición de objeto de reflexión por parte de la disciplina urbanística.

La presente investigación propone interpelar los conceptos de paisaje y territorio, haciendo eje en el análisis particular del paisaje rural. La taxativa división entre lo urbano y lo rural resulta cada vez más compleja. Aquel paisaje rural, de progresión lenta, ha sufrido de manera acelerada una mutación de gran alcance. Sin embargo, a pesar de la aparición de nuevas dinámicas y procesos, aprender a leer el paisaje como compendio de la historia de transformación del territorio nos conduce a nuevos modos de afrontar su ordenación, manteniendo los testimonios de orden rural, coherentes con los modelos de identidad detectados y construyendo un sistema de pautas para la adecuada inserción de cualquier intervención (Sabaté, 2002).En así quetomamos como caso de estudio al paisaje pampeano del sur santafesino, analizando críticamente su proceso de conformacióny comprendiendo sus posteriores transformaciones, en especial las acontecidas desde las últimas décadas del siglo XX hasta la actualidad. Se considera que dicho paisaje presenta rupturas y discontinuidades respecto a su configuración inicial, pero, asimismo, se distinguen permanencias que posibilitan comprender al paisaje como una herramienta apta para enriquecer los instrumentos de planeamiento en las escalas abordadas.

La metodología empleada presenta un perfil exploratorio basado en el trabajo de campo -articulado con tareas de revisión y análisis documental sobre el tema y objeto de estudio-; junto a un perfil empírico, que privilegia como estrategia el caso de estudio. Simultáneamente se articula la conceptualización de la realidad abordada y la confrontación empírica con la experiencia concreta. Se trabaja interrelacionadamente entre ambas instancias de la investigación, a fin de precisar y redefinir conceptos que expresen de una forma más ajustada la realidad observada, como así también elaborar su síntesis,detectando las variables principales que inciden en eltema/problemainvestigado (Etulain, 2008). Las fuentes documentales utilizadas son cartografías de archivos documentales nacionales y provinciales, imágenes satelitales de Google Earth, fotografías históricas y registros fotográficos resultantes de recorridos exploratorios.

El artículo se estructura en tres partes. En la primera, se realiza una conceptualización del marco teórico, interpelando los diversos términos utilizados, partiendo del par dialéctico paisaje/territorio, para luego focalizar en las nociones de paisaje rural y ruralidad y su relación con el ordenamiento territorial. En la segunda parte, se presenta el ámbito territorial estudiado, justificando la delimitación del caso de estudio, y se desarrolla el proceso de conformación del paisaje rural del sur de la provincia de Santa Fe, para luego reflexionar sobre las transformaciones recientes de dicho paisaje, especialmente sobre sus cambios y permanencias. Finalmente, la tercera parte, a modo de reflexiones finales, se propone contribuir al conocimiento teórico y metodológico de los estudios territoriales a fin de aportar al desarrollo de nuevas

herramientas cognoscitivas e instrumentos de intervención. Se plantea, asimismo, avanzar en la construcción de un "corpus" compartido que pueda convertirse en insumo para futuros proyectos a escala regional.

\section{REVISITANDO CONCEPTOS}

Paisaje y territorio resultan dos conceptos utilizados por distintas disciplinas y corrientes teóricas, presentando definiciones variadas -e incluso contrastantes-. Entre las diversas ciencias es común la migración de palabras cuyo significado -explícita o implícitamente- a veces se conserva, pero otras veces va variando hasta convertirse en algo completamente diferente. El término paisaje es uno de esos conceptos migrantes y cambiantes con el tiempo y en su travesía interdisciplinar (Reboratti, 2011). En este sentido, nos interesa reflexionar sobre ambos términos, pero en especial sobre sus relaciones y vínculos, ya que poseen un gran potencial para los estudios y desarrollos contemporáneos de planeamiento. 
El territorio es el conjunto de elementos y acontecimientos físicos que configura un país, siendo entendido no solo políticamente, sino como región o lugar más o menos extenso. Pero para que dicho territorio se convierta en paisaje, es necesario que exista "trabazón" entre la diversidad que forman los diferentes elementos que se ofrecen y en nuestra contemplación aparecen enlazados, trabados: "la trabazón que hace que un territorio cobre el calificativo de paisaje hay que buscarla más allá de aquello que nos ofrece la madre naturaleza, más allá de su mera unión física de rocas o ríos, hay que buscarla en la cultura y el arte" (Maderuelo, 2008:7).

El territorio, resulta un concepto de gran complejidad, comprendiendo abordajes muy diferentes entre sí. Su dinámica y evolución, no es lineal ni homogénea, sino que viene gobernada por la interacción de un variado conjunto de tendencias de cambio que se superponen sobre pautas espaciales y ritmos temporales diferenciados, abarcándose unos a otros o no. Se constituye,entonces, por un conjunto complejo de estructuras cambiantes que están sometidas a los distintos procesos que le dan forma. Distintos mecanismos interactúan sucesivamente conformando su fisonomía y,justamente, es dicha fisonomía la que resulta base de la percepción que el observador tiene del territorio. De este modo, el paisaje resulta como la expresión del territorio y de sus procesos. Algunos de estos procesos -en especial aquellos relacionados con la estructura física del paisaje- se suceden a ritmos muy lentos; sin embargo, otros -particularmente los vinculados a la sociedad- resultan cronológicamente más veloces y repentinos (Español Echániz, 2008). El paisaje se manifiesta como producto del tiempo, como explica Martínez de Pisón (2009), revela lo que somos, nuestro propio sentido, constituyendo un legado cultural, un patrimonio vivo y frágil, un testigo envuelto en el trasiego del territorio. Su dinamismo comprende la evolución, la historia, el proceso. Pero, lo procesual constituye simultáneamente tanto cambio como perduración en el tiempo de la sustancia, es decir, mantenimiento vital en la acción, permanencia en la capacidad de transformación.

Aceleradas transformaciones territoriales caracterizan las últimas décadas del siglo XX: un incremento considerable del suelo urbano y una tendencia del avance de lo urbano por sobre el espacio rural. En este contexto, reflexionar y comprender el paisaje rural resulta un ámbito de oportunidad, ya que, desde la perspectiva del planeamiento territorial, históricamente se ha puesto el foco en el entorno urbano. Como propone Rem Koolhaas (Mora, 2016), hay que dejar de ignorar el mundo rural como campo de operación y debemos pensar en metodologías para un paisaje del que tarde o temprano tendremos que hacernos cargo: "el campo se está transformando incluso más rápido que las ciudades". En este sentido, los paisajes de los espacios rurales, caracterizados por el predominio de actividades agrosilvopastoriles, a las que se han sumado nuevos usos y demandas, resultan un ámbito de relevancia para el pensamiento y la acción,como explica Rafael Mata Olmo (2010), porque se trata de espacios de grandes dimensiones que prevalecen aún en extensión -en relación al mundo urbano-, aunque en general cuentan con pocos actores agrarios, productores y gestores del paisaje, frente a muchos usuarios y agentes no agrarios que tienden a presionar por el cambio de usos o por acceder públicamente a los valores de dicho paisaje. A su vez, existe la tendencia a una cierta mitificación y simplificación del paisaje rural por parte de la sociedad mayormente urbana, dado que se percibe al campo como estático y homogéneo, ignorando la diversidad de contextos socio-territoriales y de las dinámicas que presenta.

El paisaje rural está cargado así de diversas imágenes estereotipadas, siendo generalmente asociado a lo bucólico y pastoril, donde la naturaleza es predominante (a pesar de ser un paisaje fuertemente antropizado, en donde suele ser escaso -o incluso nulo- lo "natural" u "original"), resultando, en realidad, un paisaje de gran dinamismo, heterogeneidad y altamente productivo. Asimismo, también suele prevalecer la dicotomía entre el campo y la ciudad, como dos divisiones taxonómicas claras y opuestas entre lo urbano y lo rural. Parte del supuesto de que ambas realidades están perfectamente separadas y suelen caracterizarla por diversos pares también dicotómicos, como: atraso-modernidad, lentitud-dinamismo, conservadorprogresista, aislado-integrado, lejano-cercano, etc. Para cualquiera que tenga una mínima idea de la realidad rural en la actualidad, es evidente la falacia de ese enfoque, y esa falacia, a medida que se producen fuertes procesos de cambio en el campo, se hace cada vez más evidente (Castro, 2007). Esta clasificaciónsimplista y reductiva, resulta un postulado no válido para las actuales transformaciones territoriales, en donde cada vez más dinámicas y espacios no pueden encasillarse en ninguna de las dos categorías, sino que dicho par dialéctico (urbano/rural) es cada vez más complejo y con mayores puntos de fricción.

Incorporar la perspectiva territorial como modo de superareste reduccionismo, hace necesario introducir una forma de construcción social mucho más sensible a la estrecha relación entre los factores localizativos de la actividad económica y los asentamientos humanos que de ella dependen. La oferta de recursos naturales determina patrones de apropiación y permanencia en el territorio, que explican el papel determinante de la 
ruralidad en la construcción histórica de la identidad de cada territorio en sus diversas dimensiones: económica, ambiental, social, cultural, histórica y política (Echeverri y Ribero, 2002: 24). Por su parte, el Instituto Interamericano de Cooperación para la Agricultura, reconoce que una visión territorial de lo rural que incluya los asentamientos urbanos que a este ámbito se vinculan, "permite visualizar la multiplicidad de funciones vinculadas al desarrollo agrícola, agroindustrial y artesanal, a los servicios, turismo y cultura, a la conservación de la biodiversidad y de los recursos naturales, es decir, de los ecosistemas locales y globales sustentadores de la vida y de actividades productivas" (IICA, 2000:10).

Considerar al medio rural inserto en un sistema territorial aporta dos aspectos fundamentales a la discusión. Por un lado, entender al territorio como una construcción histórica que refleja las relaciones sociales internas y externas y el modo en que una sociedad se ha apropiado de y modificado al ambiente, permite incorporar al análisis la diversidad de factores del sistema de relaciones, trascendiendo ampliamente el aspecto agrícola, considerado de modo casi exclusivo por las teorías tradicionales. Esto conduce a que la unidad de análisis deja de ser la unidad productiva agropecuaria para ser el territorio como tal, con el conjunto de actividades que en él se desarrollan - tal como lo supone la definición de territorio aquí adoptada. Por el otro, significa comprender que las áreas rurales no funcionan como un sistema cerrado, que puede analizarse y comprenderse en sí mismo, sino que, como producto de un modo histórico de relación entre el hombre y el medio natural, son parte de un modo de organización social que no puede dejar de considerarse. Con esto se supera la visión de lo urbano y lo rural como conceptos contrapuestos y se convierten, éstos, en partes integrantes de un sistema territorial en el que mantienen vínculos y relaciones.

Si se propone de afrontar el desafío de planificar e intervenir en estos territorios no urbanos, previamente hay que llenar un enorme vacío de conocimientos; ya que hay que comprender los territorios entendidos como factores y no como simple soporte de su transformación, entenderlos a partir de su estructura, de su imagen física y de su construcción histórica. Es necesario aprender a leer el paisaje como compendio de la historia de transformación del territorio (Sabaté, 2002).De manera que, al develar la relación paisaje y territorio, podemos utilizar los valores y criterios del paisaje ${ }^{1}$ como instrumentos de planeamiento, a fin de frenar el deterioro territorial y sustituyendo los criterios urbanísticos de maximización de beneficio por criterios de ordenamiento territorial en los que se contemplen los valores perceptivos, la identidad e historia de cada territorio (Maderuelo, 2008).

\section{CONFORMACIÓN Y TRANSFORMACIÓN DEL PAISAJE RURAL PAMPEANO ARGENTINO.}

\subsection{Delimitación del sector de estudio: Paisaje rural en el sur de la provincia de Santa Fe.}

La ecorregión pampeana es considerada como el sistema de praderas más importante en argentina e incluye gran parte de Buenos Aires y Entre Ríos, el centro y sur de Santa Fe, el centro y sudeste de Córdoba y el noroeste de La Pampa. Su nombre viene de la voz que significa, en el antiguo idioma de los quichuas, "campo raso", "llanura". Ya desde 1830 hubo numerosos intentos de definir sus subregiones a partir de diversas clasificaciones. Una de las más difundidas, establece que "la pampa propiamente dicha, la pampa húmeda o del litoral, se caracteriza por sus plantas herbáceas y sus gramíneas tiernas, la ausencia de bosques naturales y la horizontalidad casi perfecta del terreno" (Williams Alzaga, 1955:21).Dentro de esta subregión se encuentra el sur de la provincia de Santa Fe, área de estudio de este trabajo, la cual según Barsky (2003), es una de las áreas más propicias del mundo para la producción de granos y carnes.

La construcción de la pampa como el paisaje más representativo de la Nación Argentina tuvo lugar en la segunda década del siglo XX, luego del centenario de la independencia. En esta operación, la pampa remplaza a la Argentina (Silvestri, 2011), de manera tal que se suprime la diversidad de situaciones y características particulares de cada territorio singular,en orden de producir una imagen homogénea de la región. Es en este sentido, que entendemos fundamental recuperar las cualidades identitarias del paisaje rural del sur de la provincia de Santa Fe. Para esto, partimos deadvertir que en esta área tuvo lugar la construcción de un paisaje pampeano singular, resultado de transformaciones en el ámbito rural que diferencian este sector del resto de la región pampeana. Es importante resaltar queen el sur santafesinotuvo lugar el proceso de colonización agrícola más importante del país, producto no solo de la coyuntura política y económica de mediados del siglo XIX, sino de las particularidades del paisaje ganadero precedente.

\footnotetext{
${ }^{1}$ Si bien ni los propios campesinos, que viven de la explotación del territorio, ni los especuladores que proponen el incremento y transformación de los usos del suelo, suelen ser capaces de ver paisaje en el territorio, sí lo valoran como bien productivo. Justamente, aún en la actualidad, paradójicamente en el medio rural, el término paisaje aún resulta difícil de comprender (Maderuelo, 2008:7)
} 


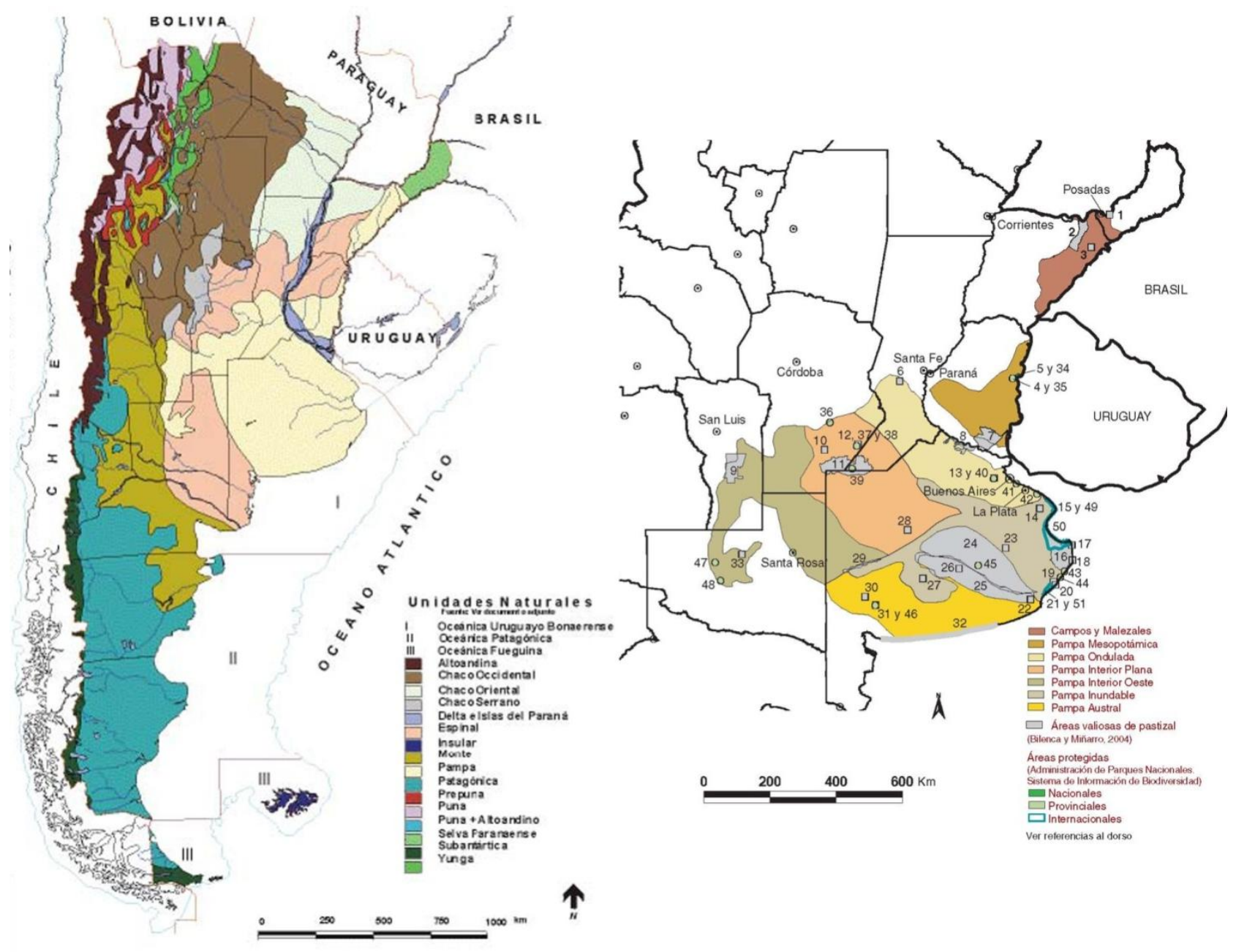

Ecorregiones de Argentina. Subreregiones de la Pampa.

(Burkart, 1999 - Viglizzo; Frank;Carreño, 2005)

\subsection{Conformación del paisaje rural santafesino.}

La introducción de ganado (vacuno y caballar) por parte de los colonizadores, en el siglo XVI generó modificaciones tanto en la naturaleza como en las prácticas de las poblaciones nativas, quienes adoptaron al caballo como medio de transporte y lo usaron para la caza. Esto derivó en un desplazamiento de los aborígenes, de las márgenes de los ríos al interior de la colonia. Asimismo, la existencia de un nicho ecológico vacante -el de los grandes mamíferos- permitió la rápida reproducción del ganado cimarrón. Consecuentemente, los altos pajonales preexistentes se transformaron en pastos tiernos gracias al abono y el pisoteo de la hacienda, como así también por las habituales quemazones que eran una práctica común de los habitantes de la colonia. Hasta ese momento, los únicos árboles que podían sobrevivir eran el ombú (incombustible) y el chañar (se activa con el fuego), pero al modificarse los pastos, nuevas especies pudieron proliferar.

A partir de esta nueva condición ambiental, comienza a configurarse el paisaje ganadero pampeano. En esta primera etapa, que tiene lugar hasta fines del siglo XVIII, en el sur santafesino conviven dos formas de ocupación del espacio. Por un lado, principalmente en el sector que hasta entrado el siglo XIX continúa en manos de los indios, subsiste el campo abierto en el que tienen lugar vaquerías indiscriminadas con el fin de extraer cueros. Por otro lado, el territorio efectivamente controlado por las autoridades santafesinas, donde convivía la estancia primitiva con la estancia jesuítica. A pesar de que ambas se constituyen como formas de ocupar un espacio que todavía no ha sido alambrado, se puede reconocer en las estancias jesuíticas de la provincia un primer intento de estructurar el territorio.

La Compañía de Jesús, favorecida por las condiciones ambientales mencionadas, se estableció en Santa Fe y Entre Ríos. Esta orden religiosa ocupó el espacio estableciendo un sistema territorial de reducciones 
de indios y poblados. Este modelo se complementaba con la existencia de fortificaciones (fuertes y fortines) para protegerse de los ataques y robos de los grupos aborígenes no reducidos. De la misma forma dependía de las estancias que abastecían a las reducciones y que se convirtieron en la base de la economía jesuítica. Estas fueron, efectivamente, las primeras unidades territoriales de la región. En el área de estudio, podemos destacar la estancia "San Miguel", cuyas tierras comprendían "unas 20 leguas a ambos lados de la desembocadura del río Carcarañá" en el río Paraná (Calvo, 1993:69).
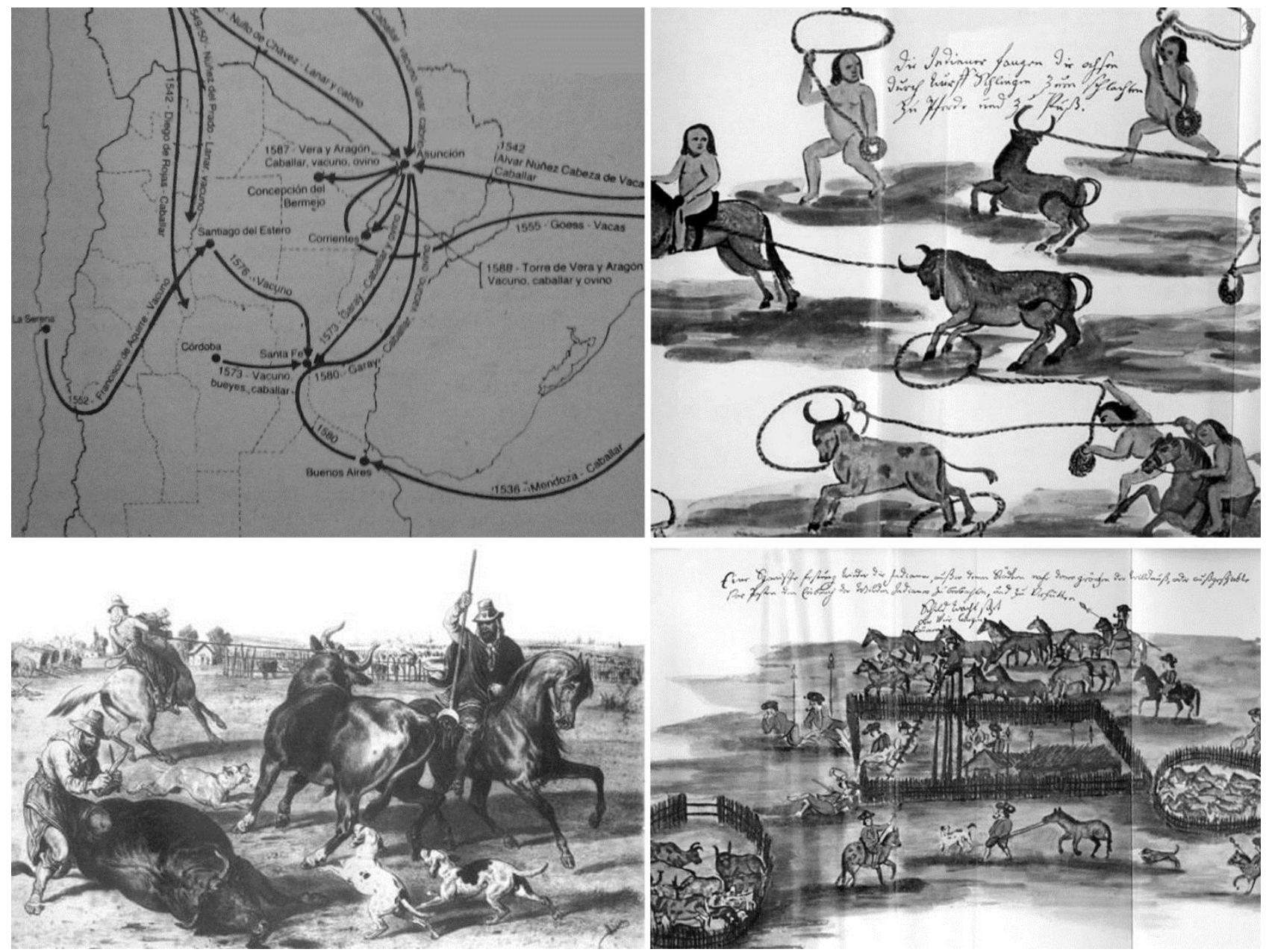

Introducciones de ganado. Trabajo con el ganado - Litografías jesuíticas (enlazando hacienda - arreos) (Gilberti, 1985 - E. Essex Vidal, 1817 - Padre F. Paucke)

El principal elemento formal de este paisaje ganadero inicial fue la división del suelo. El parcelamiento de las estancias jesuíticas era el mismo que regulaba la Corona Española para las estancias primitivas. Esta institución estableció en las Leyes de Indias que la mayor división territorial sería la "suerte de estancia". Las grandes dimensiones de las estancias de la Compañía eran, en definitiva, una sumatoria de estas unidades. Su tamaño (3000x9000 varas, equivalente a 2000ha), sus límites (el lado menor del terreno sobre un curso de agua para aprovechar al máximo este recurso, y en su otro extremo el caserío como barrera ante la inexistencia de alambrados) y su forma, estaban vinculados con las costumbres del ganado y las distancias que podían recorrer en el día hasta llegar al sitio donde se efectuaría el rodeo nocturno. El modelo de organización de la estancia jesuítica respondía a un manejo adecuado del territorio. El ganado rotaba en diferentes áreas de la estancia según el "ciclo productivo", las distintas calidades de pastos, la estacionalidad de los mismos y la variabilidad pluviométrica. En el caso de las estancias primitivas, el suelo no valía por su aptitud, sino porque su propiedad permitía obtener licencia para vaquear.

Como ya mencionamos, la localización de las estancias estaba vinculada con la presencia de un curso de agua necesario tanto para el consumo animal, como vía de comunicación y transporte. Hasta su expulsión, buena parte del movimiento de mercancías estaba en manos de los jesuitas, quienes poseían una flota fluvial de algunos barcos de buen tamaño, embarcaciones pequeñas y flotillas de canoas (Barsky; Djenderedjian, 2003). De la misma manera, el transporte terrestre a través de los "caminos de postas" tenía un rol fundamental en la estructuración de este territorio. Estos caminos eran las únicas vías seguras para 
recorrer el campo abierto, una de sus características principales es que contaban con parajes de descanso cada 4 u 8 leguas.
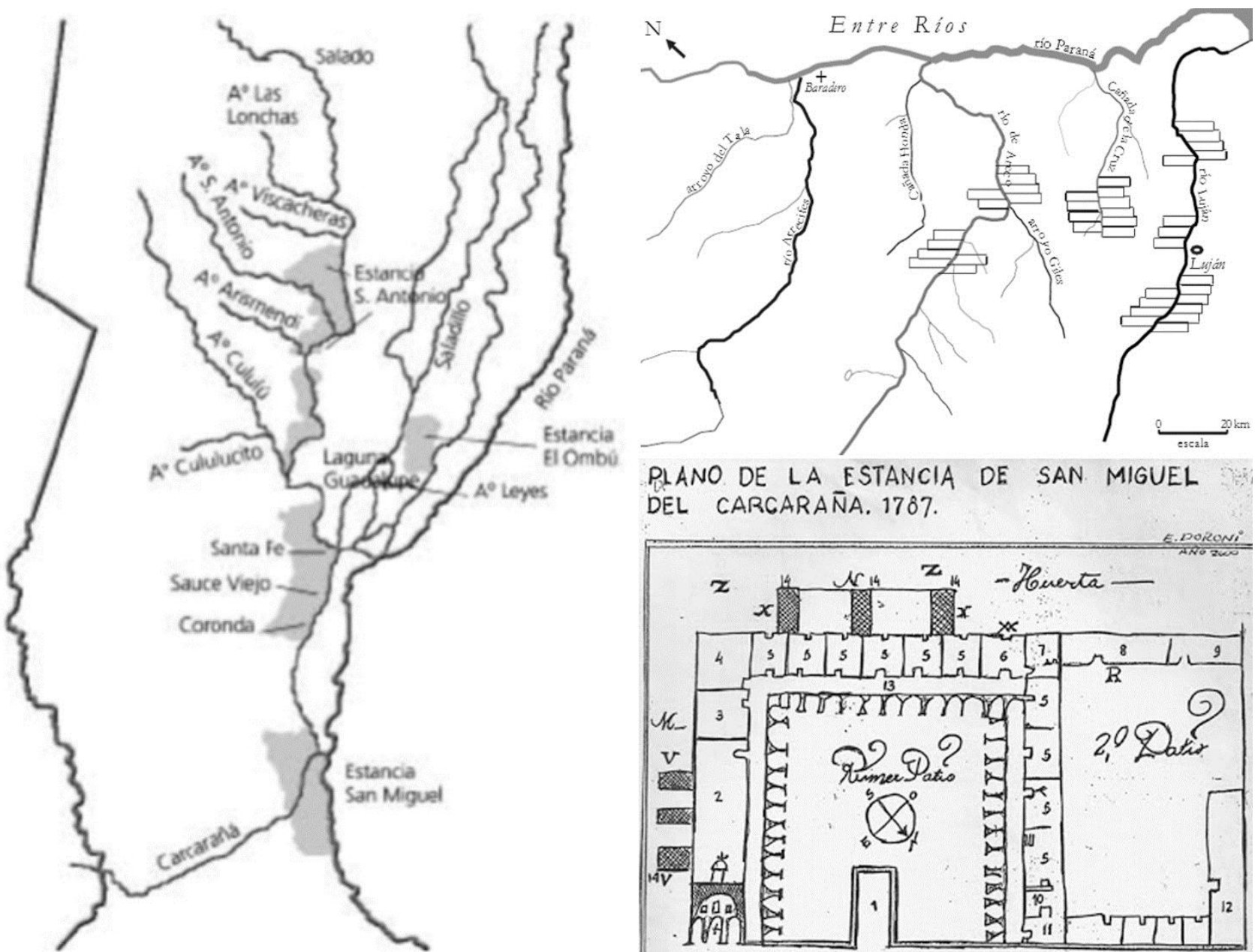

PLANO DE LA ESTANCIA DE SAN MIGUEL DEL CARCARAÑA. 1787.

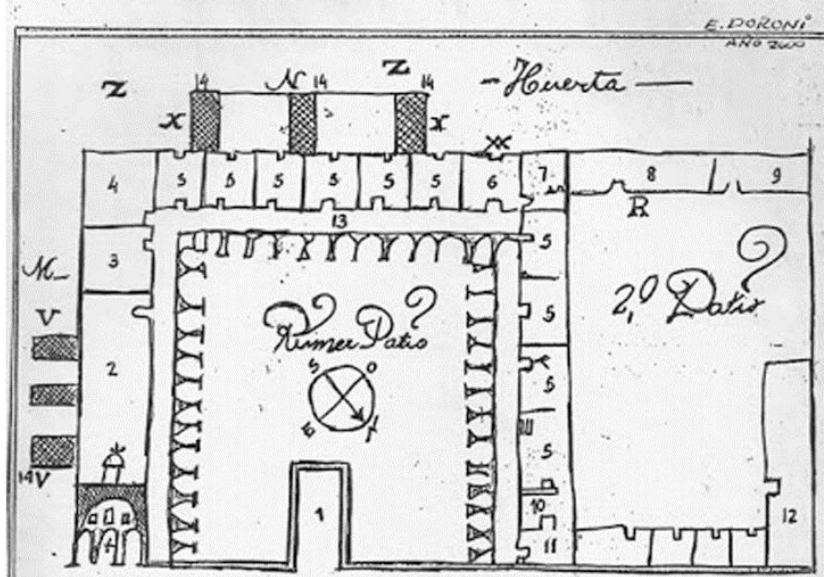

Ubicación de las estancias jesuíticas - Tipo y tamaños de "suertes de estancia" - Estancia San Miguel de Carcarañá en 1787 (L. M. Calvo - J. Garavaglia, 2000 - L. M. Calvo, 1993)

En lo que respecta a los asentamientos humanos y productivos, es importante destacar que se trataba de un sistema de ocupación territorial sumamente disperso, pero con una clara disposición al interior de las estancias. Ante la inicial inexistencia de alambrado, se dependía de los corrales a palo y pique y de la marca de ganado como medios de control espacial. En el caso de la estancia jesuítica, los núcleos poblados tenían una jerarquía según su rol territorial y ubicación geográfica (puestos/postas/fortines) y según las actividades que allí se desarrollaban (amanse/cría/engorde). Asimismo, de esta jerarquía dependían las edificaciones con las que contaban (casco/capilla/ranchos/corrales) y la población necesaria para las tareas que allí se realizaban. Por otro lado, a fines de este período y hasta mediados del siglo XIX, los establecimientos ganaderos particulares presentaban una relación jerárquica entre las instalaciones centrales que constituyen el comúnmente llamado "casco de estancia", donde se ubican los corrales, galpones, residencia de propietarios y peones solteros, comedor para personal, etc., y los "puestos", viviendas pequeñas donde reside una familia, encargada de atender y cuidar una porción de la finca.

Más allá de los componentes formales que determinaron la construcción de este paisaje ganadero, entendemos que el estudio desde la mirada del paisaje implica atender asimismo a su construcción simbólica. Fundamentalmente si tenemos en cuenta que fue el paisaje ganadero el que se consagró como símbolo nacional. Para explicar esto, es preciso subrayar que fue la figura del gaucho, habitante representativo de la pampa, la que convirtió a este paisaje en icónico. De la misma manera, cabe destacar que fue, principalmente, en clave literaria su difusión. Recorrido que comienza por los relatos de viajeros del siglo XIX, y continúa en el género de la novela, el cuento y hasta en el teatro. Asimismo, la historiografía argentina coincide en que fue durante el centenario argentino, alrededor de 1916, cuando el campo intelectual vio la necesidad de definir las bases de la identidad nacional. En este contexto, el Martín Fierro, poema narrativo escrito en 1872 por José Hernández, se presenta como el texto fundador de la Nación. 

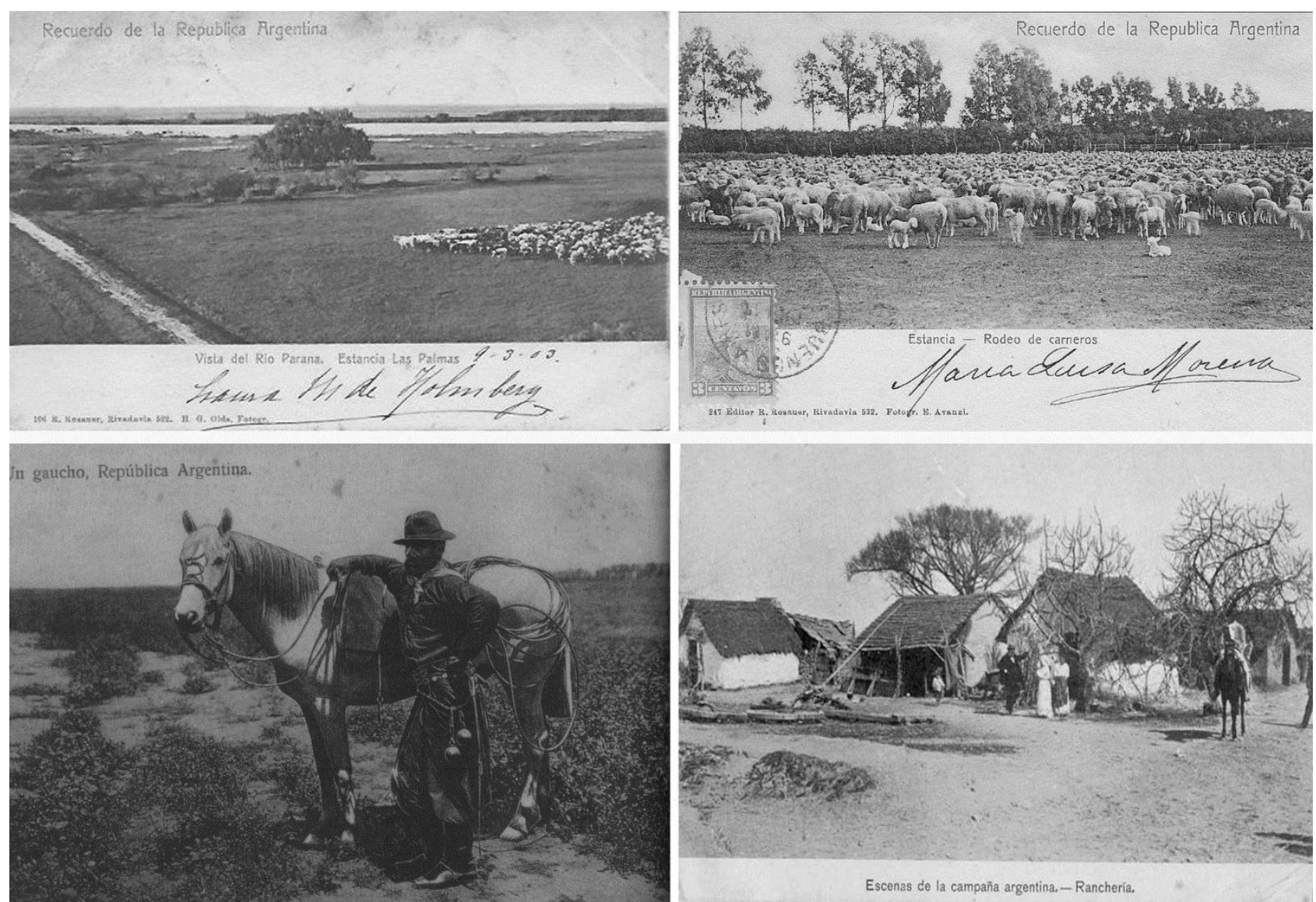

Postales del paisaje ganadero difundidas a principios del siglo $X X$ Archivo digital www.delcampe.net

Aun cuando el sistema de explotación de las estancias evoluciona, desde la simple extracción del cuero hacia la producción de carne salada para la exportación, hasta 1850 no hay grandes transformaciones en el paisaje agrario, puesto que las modalidades de distribución de la tierra y la actividad productiva fundamental -la ganadería- no difieren sustancialmente de las del período hispánico. La orientación pastoril de la economía litoral argentina continuó estimulando la cesión de enormes porciones de tierras del dominio público a particulares, tanto dentro como fuera de la línea de frontera. La tierra se encontraba dividida en grandes propiedades en manos de pocos propietarios, a excepción de las áreas cercanas a las poblaciones, ya fragmentadas en pequeñas chacras o quintas.

Entre 1855 y 1875 se producen cambios que suponen, tanto una suerte de "revolución productiva", como una radical transformación de los patrones de asentamiento precedentes. Sobre un espacio dominado aun por la ganadería, dónde la "suerte de estancia" seguía siendo la unidad productiva mínima; y donde la estancia orientada hacia la producción de cuero y carne salada había mantenido los campos sin cercar ni subdividir, y con la sola vegetación de los pastos naturales, un patrón geométrico de pequeñas parcelas de veinte a veinticinco cuadras, destinado a la explotación agrícola por parte de colonos predominantemente extranjeros, -suizo, italianos, franceses-, se extiende sobre vastas porciones del territorio.

Y esto es así porque en las décadas de 1850 y 1860, junto con la organización del Estado nacional, se registra la consolidación de ciertos factores jurídico-institucionales y políticos que preparan el campo propicio a la extraordinaria difusión de la colonización. En ese mismo período, en la provincia de Santa Fe tiene lugar la infraestructuración ferroviaria y portuaria mediante la introducción de capitales extranjeros, particularmente ingleses y franceses; la puesta a punto de un vasto programa de colonización de tierras mediante cesiones de tierra pública, expropiaciones, exenciones impositivas y estímulo a la formación de compañías ferroviarias; el fomento a la inmigración mediante la promulgación de una serie de leyes de inmigración, la formación de Comisiones de Inmigración y el contrato con compañías -vinculadas, las más de las veces, a las empresas de colonización-, o agentes promotores privados. Como sostiene Romain Gaignard (1966), la pequeña propiedad de explotación cerealera, originada a partir de la colonización ha pasado a constituir en esta zona un "tipo estructural", que desplaza a la gran estancia del período anterior. 
El paisaje agrícola, bajo esas condiciones, no se manifiesta como una construcción gradual, realizada por sucesivas generaciones de agricultores, sino como la materialización de una precisa modalidad organizativa de la producción, -la colonia agrícola-. De todas maneras, el paisaje ganadero precedente había llevado adelante una transformación del sistema ecológico a través de dos siglos, proceso que dejó como herencia un suelo fértil, apto para la agricultura. Sin embargo, a pesar de que esto haya sido un factor determinante en la valorización del suelo rural de este sector, la misma estuvo estrechamente asociada al valor expectante que adquirieron estas tierras ganadas a los indios en la expansión territorial de las fronteras santafesinas. Es así que la colonización agrícola adquiere, en el breve lapso de dos décadas (1870-90), una escala tal que da como resultado una nueva forma del territorio, que puede sintetizarse a partir de los elementos formales que definen su construcción.

En primer lugar, destacamos la sistemática geometrización del suelo que tuvo lugar a partir de la fundación de las colonias agrícolas. Esto fue posible a partir de un acelerado proceso de regularización de catastros y títulos de propiedad por parte del Estado. En estos se representan claramente las modificaciones en el tamaño y las características de las explotaciones rurales, en comparación con las preexistentes estancias ganaderas. Estas nuevas unidades de propiedad conforman una trama cuadrangular de dimensiones pequeñas que oscilan entre las 33 y 42 ha, conformando tanto patrones rectangulares como cuadrados. Sus medidas refieren a la mínima unidad de producción, en ese momento ligada al cultivo de trigo. De todas maneras, la singularidad de esta forma de subdivisión del suelo reside en que no tiene una disposición en el territorio regular y continua, pero si una vinculación estructural en relación a la planta urbana de cada colonia.

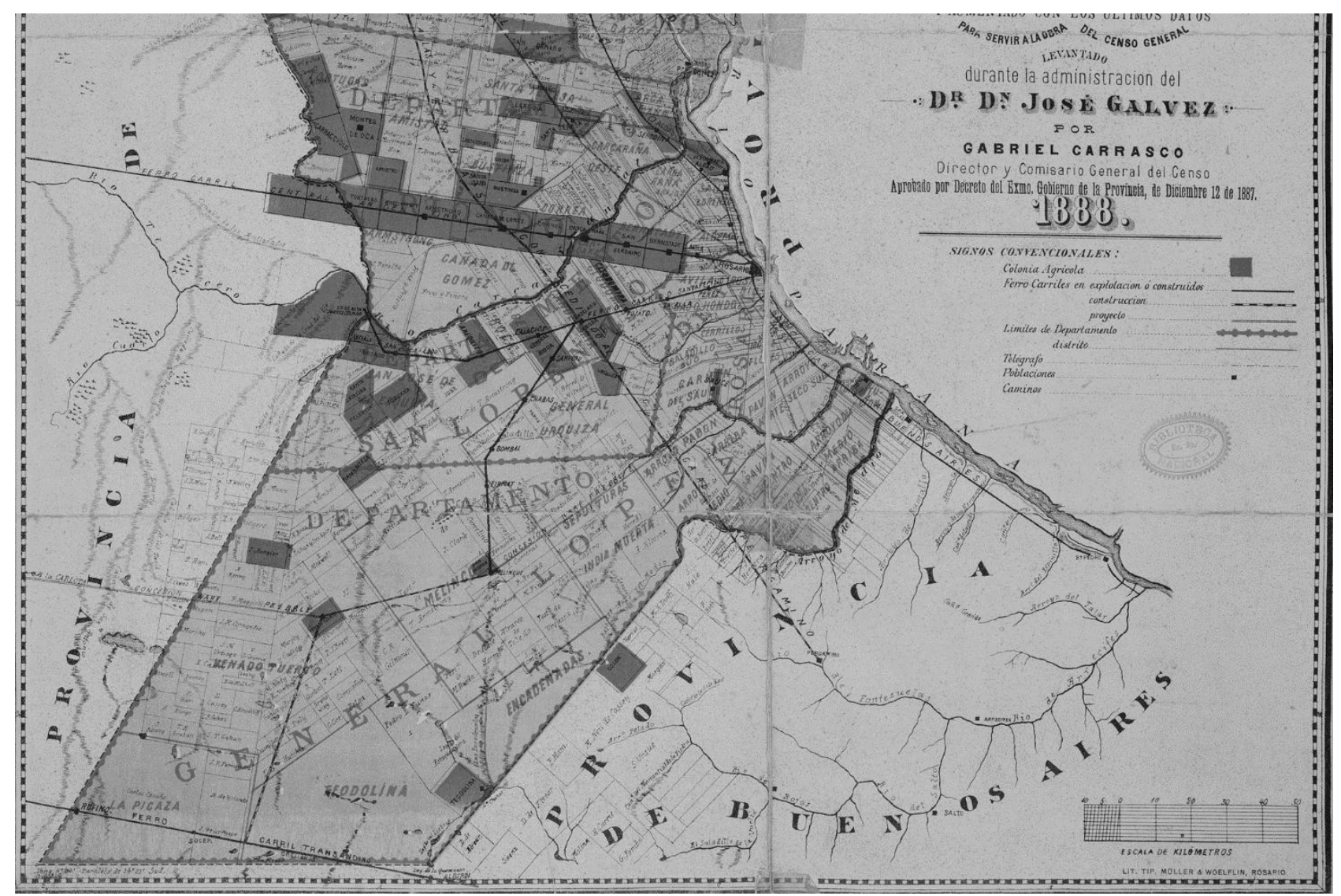

Fragmento plano Provincia de Santa Fe. G. Carrasco, 1888.

Archivo General de la Nación

Esta particular forma de ocupación del territorio no está vinculada a la presencia de determinados componentes naturales, como podrían ser el relieve, los cursos de agua o la vegetación; ni en relación a centros poblados preexistentes. En este caso, es la infraestructura ferroviaria la que, con el objetivo principal de conectar los lugares de la producción con los puertos de salida a los mercados internacionales, se convierte en la componente estructural más significativa de este paisaje. Es así, que los tendidos ferroviarios inciden directamente sobre la nueva organización, marginando o excluyendo ciertas áreas, y colocando otras en un rol protagónico. En definitiva, podemos decir que esta modalidad de ocupación 
tensionada por la linealidad de las vías ferroviarias es un rasgo que lo diferencia de los procesos de configuración de las colonias del centro de la provincia de Santa Fe.

En lo que respecta a los asentamientos humanos rurales, es importante resaltar que, a pesar de estar próximos a los centros urbanos de las colonias, presentaban una forma de ocupación dispersa en la que cada parcela rural estaba en manos de un colono y su familia. Este sistema propició tanto una regularidad en la distribución de la vivienda rural, como la inexistencia de relaciones jerárquicas entre las mismas. En este sentido, tuvo un rol central la empresa colonizadora, ya que proveía a los colonos a su llegada de una casa de madera en la parcela adjudicada, con el compromiso de realizar en ellas mejoras. A raíz de esto, mientras que en el resto del país se produce en este período un notable crecimiento de los centros urbanos y la correlativa declinación de las zonas rurales, en Santa Fe la población rural continúa aumentando.
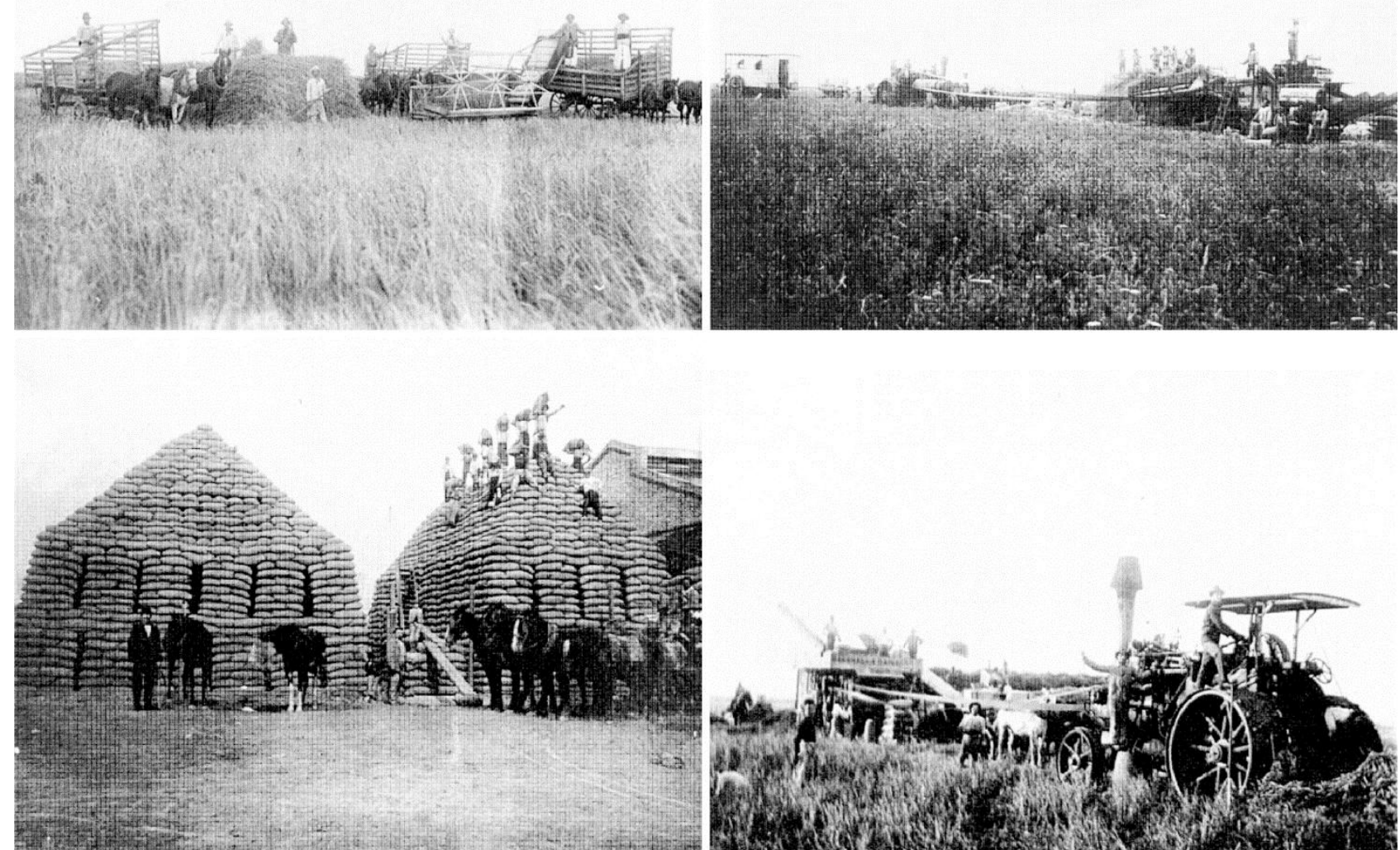

Colonias agrícolas en las primeras décadas del siglo XX.

(Archivo Museo de la Ciudad de Cañada de Gómez, Provincia de Santa Fé, Argentina)

Respecto a la construcción simbólica del paisaje agrícola, es importante destacar que ya desde la creación de la Constitución Nacional Argentina en 1853 la colonización agrícola comienza a aparecer en el discurso político e intelectual como el proyecto de país deseado. Entre estos alegatos prevalece el de Domingo $\mathrm{F}$. Sarmiento, quien encuentra en Estados Unidos un modelo a imitar al que destaca como un sistema de colonización que combina ideas liberales y democráticas. En este contexto, las colonias agrícolas de la provincia de Santa Fe se perfilan como "una alternativa que parece responder fielmente al idilio del agrarismo jeffersoniano: una articulación entre tierra y máquina (...), una democracia de pequeños propietarios que trabajan su tierra" (Silvestri, 2014:252). Esta experiencia no adopta el modelo estadounidense como se pretendía con la Ley Avellaneda, pero sí se presenta como una forma alternativa de poblar el territorio que pretende simbolizar su ideal. 

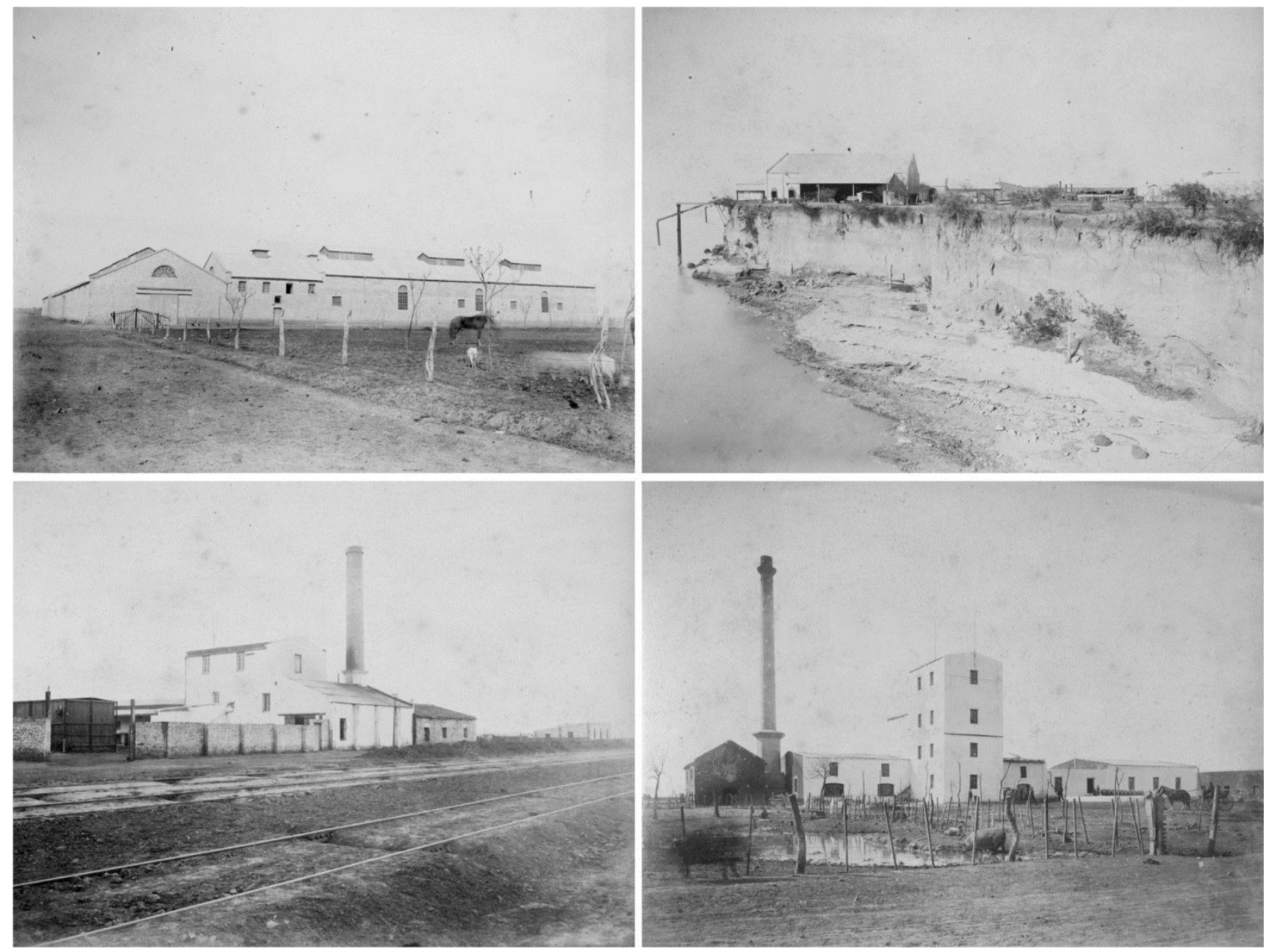

Graneros, molinos y destilería en las colonias del sur de Santa Fe (Schlie, 1888)

Sin embargo, detrás de estos proyectos existían ideas de paisajes diversas. Por un lado, en Norteamérica fue la idea de wilderness asociada a la categoría estética de lo sublime la que subyacía. Por otro lado, en Argentina fue la fórmula civilización y barbarie, difundida también por Sarmiento, la cual identificaba como desierto a los territorios no colonizados de la Pampa. La categoría de lo sublime, se vinculaba a lo monótono, infinito y terrorífico, y sólo podía ser revertida con la construcción de un paisaje civilizado, a través de la estética pintoresca. Graciela Silvestri (2014: 253) lo confirma al destacar que, "en las colonias (...) el lema de la subdivisión de la tierra aparece articulado, en los relatos, con las formas a la vez cultas y naturales que debe ofrecer un jardín". De todas maneras, ambos casos tienen en común la construcción de una imagen de paisaje en la que la figura del indio es borrada del territorio a conquistar y poblar.

Concluyendo sobre la construcción del paisaje rural del sur santafesino, es importante resaltar que a pesar de que la actividad agrícola desplazó en gran medida a la actividad ganadera al centro y norte de la provincia, ambas actividades convivieron en el tiempo. Tanto es así que numerosos autores coinciden en que fue la industrialización de la ganadería la que propició el surgimiento de la actividad agrícola debido a la necesidad de producir alfalfa para mejorar la calidad del ganado. De la misma manera que autores como Gallo (1983) reconocen que las primeras colonias agrícolas de la "pampa gringa" terminaron siendo ganaderas. Sin embargo, fue tan potente la calificación de "región del trigo", como la llamara Estanislao Zeballos (1883), que el imaginario colectivo borró la presencia de la actividad ganadera en el sector después de consolidada la colonización agrícola. Sin embargo, como sostiene San Vicente (1995), en la segunda postguerra, ya iniciado el proceso de industrialización que acompaña a la sustitución de importaciones, se generaliza el uso de la tecnología en la explotación agrícola. A la vez, algunas modificaciones en los mercados y en la legislación de la tenencia de la tierra, provocan un importante traspaso de tierras agrícolas al uso ganadero, que requiere de menor utilización de mano de obra por unidad de superficie. 
El paisaje rural del sur de la provincia de Santa Fe nuevamente fue sujeto a una profunda transformación, especialmente desde las últimas décadas del siglo XX, período en el cual se sucedieron numerosos cambios en los modos de producción. Los acontecimientos político-económicos ${ }^{2}$-nacionales e internacionales- producidos desde fines de 1980 -y la posterior salida de la convertibilidad en el 2002generaron condiciones favorables para la exportación de commodities, aumentando la demanda exterior de granos y productos derivados del complejo sojero. Asimismo, con la autorización del uso de la soja transgénica en 1996 -resistente al herbicida glifosato-, junto a otras innovaciones como la siembra directa, se produjo una notable expansión de la plantación de esta oleaginosa, profundizando el proceso de agriculturación. Se generó así una reconfiguración territorial de la producción, en la cual se incrementó vertiginosamente la superficie destinada al cultivo de soja. El avance extensivo de este componente produjo un detrimento de la superficie destinada a la ganadería, siendo ésta desplazada hacia otros territorios de menor aptitud agrícola, o tendiendo a concentrarse en prácticas intensivas como el engorde a corral feedlot- (Galimberti, 2015).

Grandes extensiones sembradas y una marcada tendencia al monocultivo, caracterizan al paisaje agrario actual, directamente ligado a la intencionalidad fundacional de la colonización -economía de especulación vinculada a los mercados externos-, sin la cual no pueden explicarse, ni la construcción regular del paisaje, ni la geometría coherente de las plantaciones de árboles.Se traslada con la misma claridad esta intencionalidad fundacional a las características de las casas rurales que aún persisten en el área, y a las características tipológicas de los centros. Ambas evidencian la naturaleza de las relaciones entre formas de tenencia y explotación de la tierra y formas de organización de la población agrícola. (Martínez de San Vicente, 1995).

Por otra parte, esta producción extensiva de soja y las condiciones óptimas de puerto que presenta la orilla occidental del río Paraná, ha conducido a la instalación de grandes plantas de procesamiento y exportación de oleaginosas y derivados. Es así, que numerosas hectáreas de suelo agropecuario se transformaron bajo la incorporación de imponentes infraestructuras industriales y puertos exportadores, que interrumpen abruptamente el paisaje rural, no sólo con la incorporación de estos gigantes de acero, sino con el desfile de cientos de camiones que diariamente acceden a dichas plantas para transportar los cereales -frutos del territorio pampeano- y de buques graneleros -de banderas de distintos rincones del mundo-, que reciben los millones de toneladasanuales que salen de los puertos del sur santafesino ${ }^{3}$.

A su vez, se registra una aceleración en los cambios de usos del suelo, convirtiéndose gran cantidad de hectáreas rurales para usos urbanos. Las extensas áreas, mayormente agrícolas, que se extienden aparentemente de manera infinita hacia el horizonte, resultan fragmentadas por la aparición de nuevos usos industriales, residenciales, recreativos y del terciario, dispersos en el territorio. Nuevas figuras y componentes transforman el paisaje rural hacia un paisaje rururbano. Éste se caracteriza por la presencia de elementos o tipologías urbanas en pleno ambiente rural que, sin embargo, sigue siendo calificado como no urbano para el planeamiento: tiende a ser ocupado por invernaderos, líneas de conducción eléctrica, depósitos de maquinarias agrícolas, e incluso, por instalaciones completamente apartadas de las actividades agropecuarias, como industrias, plantas de tratamientos de residuos, carreteras y autopistas (Folch, 2003).

Justamente, la incorporación de nuevas infraestructuras de comunicación, como las autopistas, introducen rupturas y atraen cambios al territorio. Como ha ocurrido a fines del siglo XIX con el sistema ferroviario, y en las primeras décadas del siglo XX con la incorporación del sistema vial de rutas nacionales y provinciales, la incorporación de vías rápidas, en las últimas décadas del siglo XX, atraen diversas transformaciones al paisaje santafesino. Por un lado, la incorporación de estos componentes infraestructurales interrumpe y secciona el territorio, hallando paso sobre el mar de ruralidad. Por otro, éstos resultan polos atractores de actividades y usos urbanos por la accesibilidad que posibilitan. Plantas industriales, barrios abiertos y cerrados, grandes comercios o plantas de almacenaje, entre otros, tienden a localizarse junto a las autopistas; cambiando así, en gran medida, el aparentemente estático paisaje rural pampeano. A su vez, estás vías rápidas, introducen nuevos modos de percepción del paisaje, ya que incorporan la velocidad a la mirada del espectador.

\footnotetext{
2 En la Argentina se implementan una serie de cambios estructurales como: la apertura al mercado internacional, la afluencia de capital extranjero y la reforma del Estado, a través de un proceso de desregulación y de privatización de gran parte de las empresas y servicios estatales, en conjunto con un fuerte proceso de globalización. Asimismo, nuevos acontecimientos a nivel internacional como laconstitución del MERCOSUR, las demandas de modernización de infraestructuras portuariasy la constitución de la Hidrovía ParanáParaguay plantean nuevos cambios a la región paralos próximos años.

${ }^{3}$ Los puertos del sur de la provincia de Santa Fe -desde Timbúes hasta Arroyo Seco, despachan entre el $78 \%$ y el $80 \%$ de las exportaciones argentinas de aceites, granos y subproductos (Calzada y Rossi, 2016)
} 

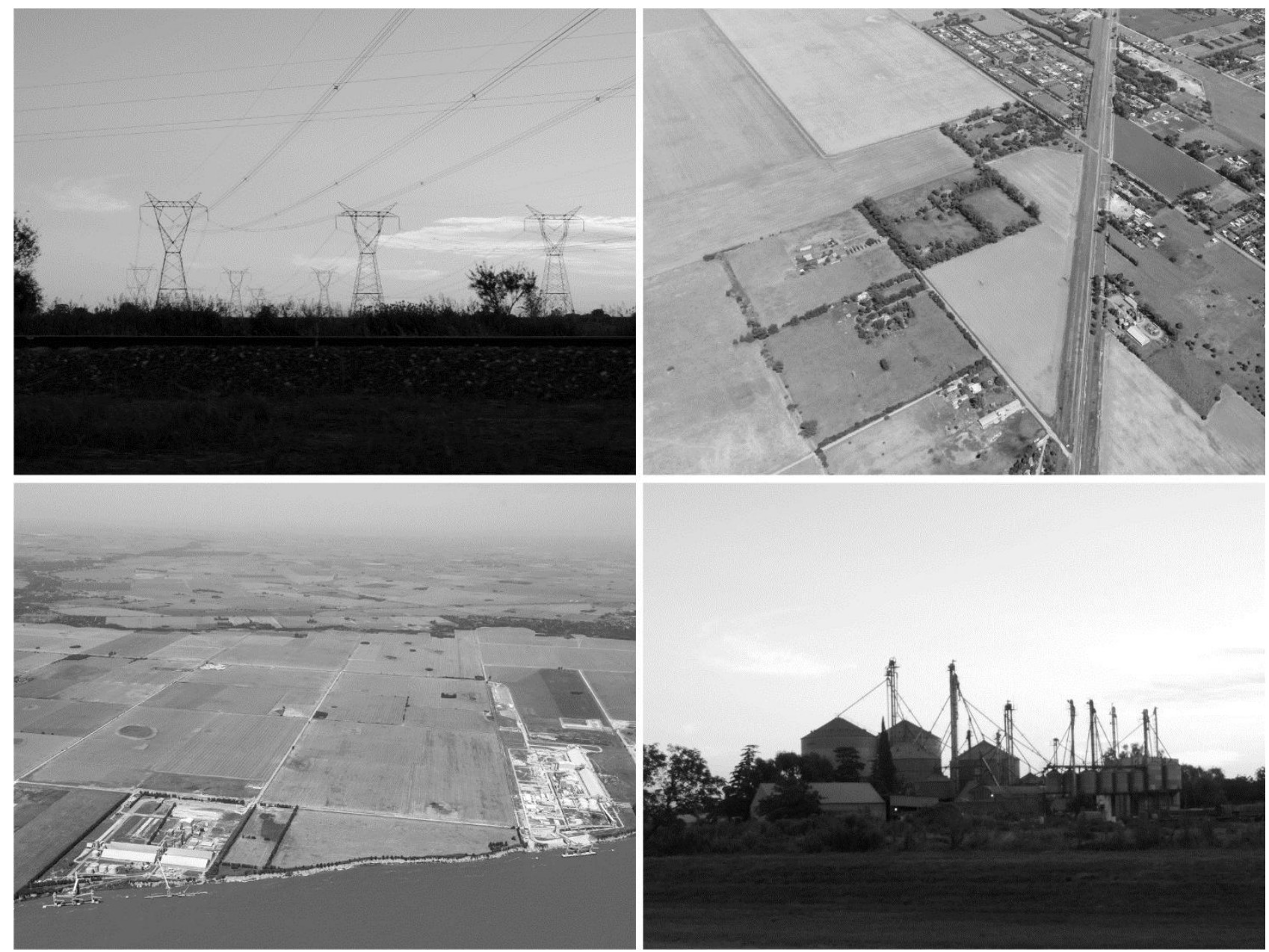

Transformaciones del paisaje rural santafesino: incorporación de nuevos usos, componentes y actividades.

Archivo fotográfico Metropolitana Unidad de Planificación, año 2014, y fotografíasde Cecilia Galimberti, año 2016.

El paisaje rural santafesino se carga así de nuevas imágenes, de nuevos componentes y elementos que transforman el territorio y su percepción. Sin embargo, a pesar de los cambios que se identifican a partir de la incorporación de nuevos usos del suelo -y las modificaciones en los modos de producción-, que tienden a fraccionar con yuxtaposición de diversas actividades las amplias extensiones rurales, también se registran permanencias de aquel paisaje que se construye entre fines del siglo XIX y XX.

Las fotografías aéreas y los catastros actuales no hacen sino evidenciar la transcripción literal sobre el territorio del patrón explicitado en contratos y mensuras, con la incorporación de la trama viaria. El análisis revela una historia reciente, casi sin alteraciones, que por su impronta y por su dimensión comienza a ser claramente visible ya sobre la cartografía 1:500.000 y la foto satelital. Es así que se registran fuertes relaciones de permanencia entre el paisaje colónico y el paisaje actual. Por un lado, se identifica una lógica del asentamiento inicial, a la cual no han podido escapar las nuevas incorporaciones -subdivisiones, carreteras, nuevos crecimientos urbanos-. La mensura original continúa imponiendo la orientación del parcelario, y es en este esquemático rigor donde radica la originalidad morfológica del asentamiento actual. Por otro, existe una notoria unitariedad que domina las relaciones entre accesibilidad territorial, territorio agrícola y centros urbanos (Martínez de San Vicente, 1995)

Asimismo, se registran numerosos elementos de permanencia. Por ejemplo, la gran cantidad de forestación foránea, introducida mayormente durante el siglo XIX, como cortinas rompe vientos y montes de abrigo y sombra para ganado, característicos de la explotación agropecuaria, si bien modifican ampliamente el paisaje original santafesino, en la actualidad resultan componentes característicos del paisaje rural argentino. También así ocurre con otros elementos recurrentes, por ejemplo: los dispositivos que permitían extraer agua de las napas, entre los que sobresale la figura del molino de viento norteamericano; los que permitían almacenar agua, fundamentalmente para la bebida de la hacienda, de los que se destaca el 
tanque australiano; y la maquinaria agrícola en toda su evolución técnica; los galpones silos para el depósito de granos.

Por otra parte, las instalaciones del sistema ferroviario que, como explicamos en el apartado anterior, resulta estructurador clave de este territorio, continúan persistentes tanto en el paisaje como en el imaginario colectivo, resultado elementos identitarios fundamentales de la pampa argentina -tanto para cada poblado, como para la región pampeana en su conjunto-. Los cuadros de estación, con las masas forestales aledañas, los tanques de agua ferroviarios -para alimentar a las locomotoras a vapor del siglo XIX-, los ríeles y durmientes de las vías, puentes, casillas, elementos de señalética, entre otros.
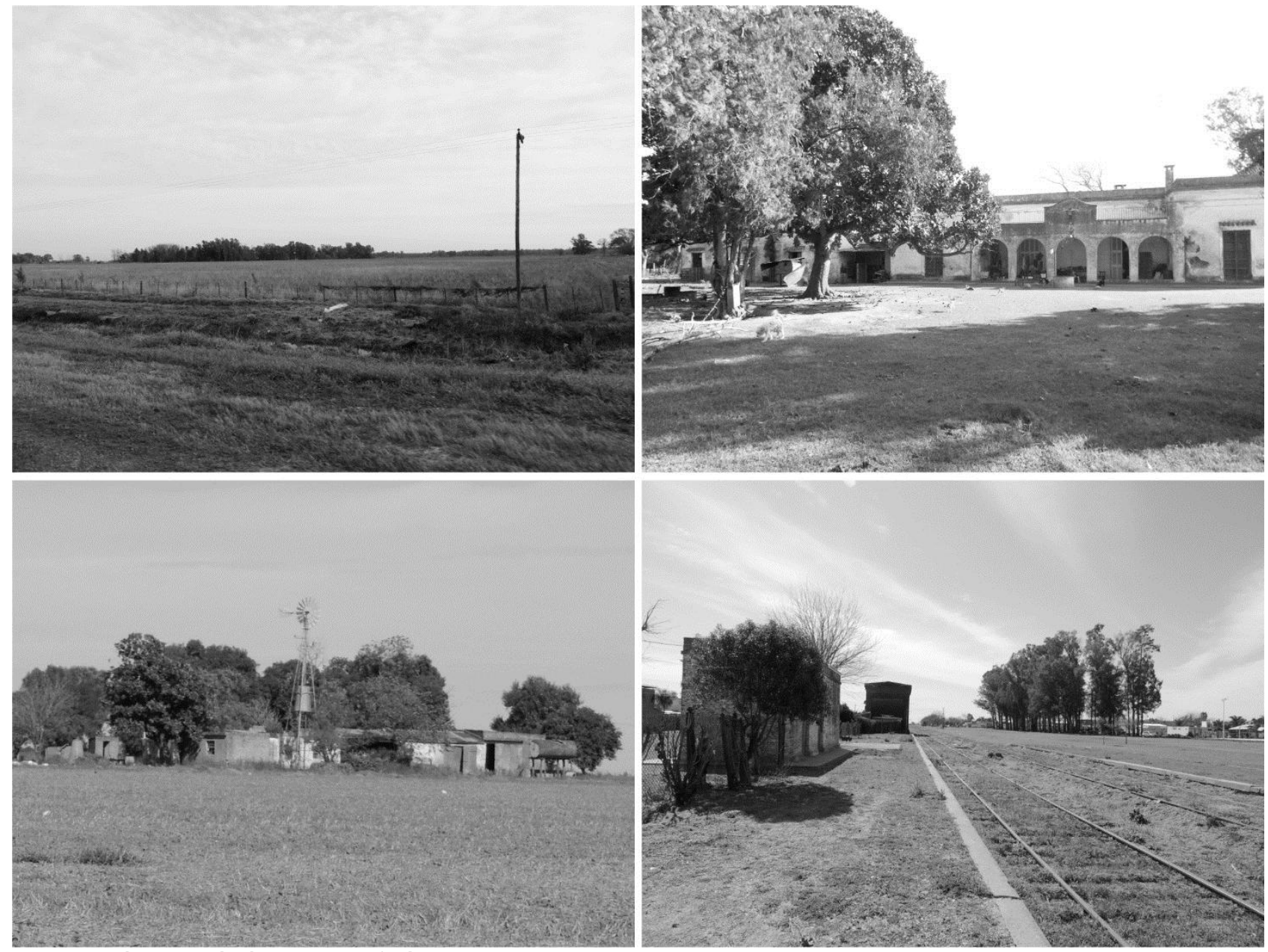

Permanencias del paisaje rural santafesino.

Fotografíasde Cecilia Galimberti, años 2014 y 2015.

De este modo, el paisaje del pasado -o aquel paisaje en el que perceptivamente se imponen las formas originadas en los siglos anteriores-, se percibe en nuestro presente reclamando un alto nivel de abstracción que escapa a la mera observación directa y constatación de rasgos temporales o de sus pautas (Español Echániz, 2008: 223). Se constituyen en tópicos, como explica Silvestri (2011:24), en los que las imágenes traducen con inocencia, permaneciendo en estado de latencia para ser retomados mucho después, con significados contrapuestos a los originales. Estos paisajes persistentes de otras épocas, ahora resignificados y cargados de nuevos sentidos -respecto al momento de su construcción-, nos remiten a la identidad del territorio y nos conducen a reflexionar sobre las aceleradas transformaciones actuales a la que está sujeto, a fin de desarrollar instrumentos de ordenamiento territorial que encaucen los nuevos procesos, pero preservando sus paisajes que lo caracterizan.

\section{REFLEXIONES FINALES}

El caso de estudio constituye en ejemplo singularmente expresivo de un proceso de construcción de simplicidad implacable que ha señalado para siempre algunos rasgos definitivos del paisaje. Nuestro trabajo 
intenta descubrirlos, explicarlos y valorizarlos, a la vez que dar respuesta a algunos interrogantes esbozados en la introducción:

El primer interrogante al que hemos intentado dar respuesta es, ¿qué nuevas miradas emergen del territorio al aproximarse a él desde el concepto de paisaje?El orden, la geometría, los caracteres distributivos del asentamiento; las relaciones entre la naturaleza "original" y la fuerza de las modificaciones que es capaz de imprimir la intervención humana a lo largo del tiempo; la influencia que adquiere la "tradición técnica", experimentada y puesta a punto en distintas intervenciones precedentes y el peso de la experiencia acumulada, sobre la caracterización actual del paisaje; el uso del paisaje, desde un punto de vista más amplio que el meramente utilitario; el descubrimiento y el intento de representación de sus potencialidades organizativas y formales con vistas a un posible transformación intencionada.

El segundo, ¿ha sido posible, a través de esta aproximación, descubrir y representar órdenes espaciales diversos de los establecidos, aportando así, de alguna manera, a la introducción de nuevas herramientas disciplinares? No sin limitaciones, dada la vastedad del área cubierta, y siendo conscientes de que aún es posible realizar infinitas aproximaciones desde otras perspectivas que seguirán aportando ulteriores interpretaciones, creemos que el trabajo descubre una interpretación espacial del territorio estudiado, que lo hace inescindible de su origen: de su condición original de territorio dominado por la explotación ganadera a su rotunda transformación mediante la colonización agrícola; de su rol en la difusión de una forma de asentamiento -el patrón de colonias- en el sur de la provincia, y en la determinación de la estructura regional en torno a la ciudad y puerto de Rosario; de su condición, por lo tanto, de unidad y coherencia respecto a una serie de características y determinantes que cobran mayor fuerza que la actual pertenencia a divisiones administrativas y políticas.

El tercero, ¿cuáles son las potencialidades organizativas y formales de este paisaje y como pueden ser utilizadas en una estrategia de planeamiento?En primer lugar, la presencia de un proceso de construcción que ha borrado todo vestigio de posibles paisajes preexistentes, y que al conservar hoy con muy escasas alteraciones sus características fundacionales, presenta una fuerte inercia a las transformaciones.En segundo lugar, el poder estructurador del sistema de los recorridos territoriales, que han contribuido fuertemente a la conservación de los caracteres originales del asentamiento. En tercer lugar, el peso de la lógica impresa por el proceso de construcción histórica de este paisaje, que continúa reglando las transformaciones físicas -subdivisiones, carreteras, nuevos crecimientos urbanos- y asegurando la unitariedad de las relaciones entre accesibilidad territorial, territorio ruraly centros urbanos continúa imponiéndose sobre las transformaciones "espontáneas", y es en este esquemático rigor donde radica la mayor potencialidad morfológica del paisaje actual.

El cuarto, ¿cuáles son los aspectos negativos, o las limitaciones morfológicas a la transformación que este paisaje presenta?La existencia de un "proyecto" de subdivisión de suelo completo, autónomo y sobredimensionado respecto de la real demanda de ocupación;la abundancia de tierra, el uso semirural de los asentamientos urbanos y la inexistencia de límites para la expansión, la dispersión y la baja densidad;la ausencia de confines precisos, la escasa definición morfológica de la centralidad, y la redundancia de áreas vacantes en el interior del trazado urbano.

Decíamos en nuestra presentación, en nuestra voluntad de entenderlo como una "construcción" a lo largo del tiempo, que nuestra intervención es sólo un momento entre el ayer y el mañana, que aspira a "proyectar" el uso -en el sentido de fruición y goce- y la forma de una porción del espacio terrestre.Si la arquitectura se presenta como una disciplina proyectual por excelencia, "trabajo sobre conjuntos ambientales a todas las escalas dimensionables,... a partir del intento de estructurar con significado todo el espacio físico que el hombre habita, ... confiriendo sentido estético incluso a totalidades cuya presencia en el mundo precede a nuestra acción directa" (Gregotti, 1972:68-69), encuentra también tanto su fuente de inspiración como su verdadero sentido transformador, en el "programa" que le permitirá llevar adelante estas transformaciones, cuyo éxito y perdurabilidad en el tiempo están en estrecha dependencia con la sensibilidad y la capacidad de interpretar ajustadamente los procesos económicos y sociales que concurren sobre esa porción del espacio en ese particular momento de la historia.

Propiedad privada del suelo, crisis del sector agrícola y acentuada dependencia de un mercado externo marcadamente proteccionista; deterioro paulatino de los suelos, disminución progresiva de los ritmos de crecimiento de la población y privatización de los sistemas de transporte; autonomía administrativa entre las distintas partes del asentamiento y excesiva centralización de las decisiones de transformación del territorio en el gobierno provincial como contrapartida; son los rasgos más oscuros con los que un proyecto de 
transformación del territorio de esta región hoy debe medirse.Cualidades intrínsecas del asentamiento, orden, accesibilidad, dimensión, patrimonio ambiental y cultural-, recursos invertidos y un cuadro social rico y complejo, son la contracara iluminada que permite entrever una infinidad de alternativas futuras sobre las que dar sentido al cambio de significado que intentamos producir trabajando desde una mirada proyectual sensible a las condiciones del paisaje.

El desafío que se nos presenta hoy, se confronta con una situación ambivalente: por una parte, de desconfianza generalizada en la planificación de escala regional o microregional, y en el Plan como instrumento capaz de orientar territorialmente las decisiones "políticas" de transformación de un territorio. Desconfianza que se apoya en el reconocimiento de la desaparición paulatina de la acción coordinada del Estado en el establecimiento de las políticas de infraestructuración y ordenamiento del territorio y su reemplazo por una multiplicidad de instancias de "concertación negociada" de los intereses contrapuestos. Por otra, de revisión profunda del concepto de naturaleza como valor "complementario" de la civilización contemporánea -esencialmente urbana-, y su reemplazo por la consideración del ambiente como "recurso", o como bien social a conservar y distribuir.

\section{BIBLIOGRAFÍA}

BARSKY, O.; DJENDEREDJIAN, J. (2003) Historia del capitalismo agrario pampeano: la expansión ganadera hasta 1895. Buenos Aires: Siglo XXI.

CALVO, L. M. (1993)La Compañía de Jesús en Santa Fe. La ocupación del espacio urbano y rural durante el dominio hispánico. Santa Fe, Argentina: Ediciones Culturales Santafecinas.

CALZADA, J.; ROSSI, G. (2016)“Commodities: $57 \%$ de la producción de soja, $43 \%$ del trigo y $40 \%$ del maíz a $300 \mathrm{~km}$ del Gran Rosario". Informativo Semanal de la Bolsa de Comercio de Rosarion 1746, año XXXIII, Rosario.

CASTRO, H.; REBORATTI, C. (2007) Revisión del concepto de ruralidad en la Argentina y alternativas posibles para su redefinición. Buenos Aires: Secretaría Agricultura, ganadería, Pesca y Alimentos.

ECHEVERRI, R.; RIBERO, M. (2002) Nueva ruralidad. Visión del territorio en América Latina y el caribe, IICA, Misión Rural, Costa Rica.

ESPAÑOL ECHÁNIZ, I. (2008) "El paisaje como percepción de las dinámicas y ritmos del territorio". En J. MADERUELO, Paisaje y territorio( 203-226). Madrid: Abada Editores.

ETULAIN, J. C. (2008) La gestión urbanística mixta de intervenciones en vacíos urbanos de ciudades centrales. Caracterización, análisis e instrumentos. En Estudios del Hábitat, nº 10, p.45-57.

FOLCH, R. (2003) El territorio como sistema. Conceptos y herramientas de ordenación. Institud d'Edicions de la Disputació de Barcelona: Barcelona.

GAIGNARD, R. y otros (1966) Estructuras agrarias pampeanas. Investigación piloto realizada para la secretaría de Estado de Agricultura y Ganadería de la Nación.Policopiado.

GALIMBERTI, C. (2015)La reinvención del río. Procesos de transformación de la ribera de la Región Metropolitana de Rosario, Argentina. Colección A\&P Tesis Doctorales, UNR editora: Rosario.

GALLO, E. (1983)La Pampa Gringa. La colonización agrícola en Santa Fe (1870-1895). Buenos Aires, Argentina: Sudamericana.

GREGOTTI, V. (1972). El territorio de la Arquitectura. Col. Arquitectura y crítica. Buenos Aires: G. Gilli.

IICA (2000) Nueva Ruralidad. Instituto Interamericano de Cooperación para la Agricultura: Panamá.

MORA, P. (2016) "Rem Koolhaas en \#CambioDeClima: "El actual desafío de la arquitectura está en entender el mundo rural". Plataforma Arquitectura, 29 de junio de 2016. Disponible en http://www.plataformaarquitectura.cl/cl/790455/rem-koolhaas-en-number-cambiodeclima-el-desafioactual-de-la-arquitectura-esta-en-entender-el-mundo-rural

MADERUELO, J. (2007) Paisaje y Territorio. Madrid: Abada Editores.

MARTINEZ DE SAN VICENTE, I. (1995)La construcción del territorio de las colonias de la "Central Argentine land Company". Tesis doctoral. Escuela Técnica Superior de Arquitectura: Barcelona.

MARTÍNEZ DE PISÓN, E. (2009) Miradas sobre el paisaje.Madrid: Biblioteca Nueva.

MATA OLMO, R. (2010). "La dimensión patrimonial del paisaje: una mirada desde los espacios rurales". En J. MADERUELO (Dir.) Paisaje y patrimonio (pp. 31-74). Madrid: Abada.

REBORATTI, C. (2011) "El paisaje como concepto migrante". En. AAVV, Miradas desde la Quebrada de Humahuaca. Territorios, Proyecto y Patrimonio, p.98-103. Buenos Aires.

RAMOS, J. (1992). La aventura de la Pampa Argentina. Arquitectura, ambiente y cultura. Buenos Aires, Argentina: Corregidor 
SABATÉ, J. (2002) "En la identidad del territorio está su alternativa". OP Ingeniería y territorio, vol. 60, p. 1219.

SILVESTRI, G. (2014). "El imaginario paisajístico en el litoral y el sur argentinos". En M. BONAUDO (Dir), Liberalismo, Estado y orden burgués (1852-1880): Nueva Historia Argentina (Vol. 4). Buenos Aires: sudamericana.

SILVESTRI, G. (2011) El lugar común. Una historia de las figuras de paisaje en el Río de la Plata. Buenos Aires: Edhasa.

WILLIAMS ALZAGA, E. (1955) La Pampa en la novela argentina. Buenos Aires: Estrada.

ZEBALLOS, E. (1883) Descripción amena de la República Argentina. Tomo II. La región de trigo. Buenos Aires: Peuser. 